\title{
Entrepreneurship and Art Education Tourism: A Study on Results of Management Skills Training Program for Students
}

\author{
Trianti Nugraheni, Agus Budiman, Yudi Sukmayadi ${ }^{\bowtie}$ \\ Department of Dance Art Education, Faculty of Arts and Design Education, \\ Universitas Pendidikan Indonesia
}

Received: September 26, 2019. Revised: November 16, 2019. Accepted: December 24, 2019

\begin{abstract}
Entrepreneurship, in the context of the development of art education tourism programs in higher education, is regarded as a serious concern in reflecting the role of universities in developing the tourism industry. This is considered as the universities' efforts of innovation and creativity to improve the competitiveness of higher education goals through the development of entrepreneurship in the field of educational tourism. This paper discusses the role of tertiary institutions in developing educational tourism entrepreneurship, which in its implementation empowers potential students by providing entrepreneurship training for them to be able to manage art education tourism program events. The data were obtained by test and questionnaire were given to 30 students at Universitas Pendidikan Indonesia who were involved in the activities of entrepreneurial training programs in the management of tourism education through the art business. The program was established by cooperating with universities, the local government, as well as non-governmental institutions.
\end{abstract}

Keywords: Entrepreneurship; Art Education Tourism; Skills Management Training

How to Cite: Nugraheni, T., Budiman, A., \& Sukmayadi, Y. (2019). Entrepreneurship and Art Education Tourism: A Study on Results of Management Skills Training Program for Students. Harmonia: Journal of Arts Research And Education, 19(2), 193-203.

\section{INTRODUCTION}

Efforts of nurturing and developing students' entrepreneurial characteristics are most effective to begin from the university (Hidayat \& Alhifni, 2017). A higher education institute should be the vessel in embedding entrepreneurial skills to students (Widyana, et al., 2018). That being said, it is essential to establish a course specifically designed to teach entrepreneurial skills to students and to incorporate it into the curricula of higher education programs. Entrepreneur education in higher studies is critical to adapt to the cur- rent entrepreneur-based global economy (Kodrat \& Hindarto, 2012). Moreover, advanced entrepreneur education should instead be regarded as a necessity rather than a formality (Maryanti, 2017). Related to the notion, Universitas Pendidikan Indonesia (UPI) requires to take into account the development of entrepreneurial courses in existing programs as a means of preparation for the students to compete in the work field and global economic society. Entrepreneurship and tourism education is currently growing as one of the most demanded aspects to be developed in education field (Ndou et al., 2018) in all

\footnotetext{
Corresponding author:

E-mail: yudi.sukmayadi@upi.edu
} 
levels, including UPI as a higher education institute.

Along with the change in the university's status from Higher Education Institution as State-owned Legal Entity (PT BHMN) to State Higher Education Institution as Legal Entity (PTN-BH) as stipulated by Higher Education Institution Law No. 12/2012 regarding changes in higher education institutions' management system, UPI is granted the authority and autonomy to manage its own business in either academic and non-academic aspects. When a State Higher Education Institution (henceforth, PTN) possess academic autonomy, it is granted the independent authority to develop its academic coverage, upgrade the curriculum, establish new majors and facilities, improve assessment systems, and conduct other activities without interference from any parties. In addition to academic affairs, a PTN is also allowed to make financial decisions independently in determining the budget allocation and finding new financing sources. The PTN is also able to determine the management system of students' affairs, organizations, infrastructure, and employment. In this regard, students bear a central role in the university's strategic policies through students' organization.

Following the status change, the UPI is required to implement a proper paradigm shift in managing the autonomy granted. The incorporation of proper mechanisms in the effort of optimizing the university's potentials, e.g., physical infrastructure and human resources are essential to support the achievement of the university's vision and missions that are embedded in the university's policy program and the university's 2016-2020 strategic plans.

Among the new potentials in newly-stipulated regulation regarding UPI's authority and autonomy, it is interesting to take into account the financial management aspect; this includes the university's autonomy to develop and generate new funding sources e.g., from products of education and partnership services as additional income to the university's treasury. Therefore, the university needs to formulate policy on business unit developments in its institutions.

The previously-mentioned duties and responsibilities a university bears are reflected in the graduates' quality and competitiveness in the work field. Within this regard, one of the success indicators of a university in implementing education is the graduates' rate of employment. Therefore, innovations in educational approaches, both intra and extracurricular activities, are highly required in producing university graduates with high competence and competitiveness. Grade Point Average (GPA) is no longer adequate as the only indicator of students' competence; one should also consider the students' technical competence and competitive attitude prior to entering the work field.

The Faculty of Arts and Design Education at UPI offers three specialized programs in art, i.e. dance, musical, and fine arts. The Fine Arts program also offers a specific course in design art. The Faculty's vision, missions, and objectives, in general aim to prepare graduates with high competence in attitude, knowledge, and skills as future educators in their respective fields. In reality, the faculty graduates' job profile is quite varied, not only as art teachers in formal education institutions, but also as the owners of self-established art studios (e.g., dance studio, makeup studio, and fashion studio) that offer packages of art services to the consumers. The graduates who choose non-education oriented jobs are highly competitive as well compared to those who teach art in schools.

The current demands of the global economy posits new challenges in efforts of improving human resources quality to produce graduates with an entrepreneurial and independent mindset in instigating new job opportunities rather than expecting to work in existing job fields. The idea of an entrepreneurial mindset highly relates to an individual's self-confidence in one's own survival in a highly competitive community. In establishing new job op- 
portunities, one is compelled to possess an adequate set of skills regarding the respective business fields; in this regard, strategic support from universities in terms of the development of higher education business is needed to nurture students' entrepreneurial skills.

In line with that, one of the ways to enhance students' competence in business management of art services is by providing programmed and sustainable entrepreneurial training of prerequisite skills and knowledge, e.g., event planning, marketing, event organization, up to program evaluation. The rationale of the training program lays its basis on the notion that students in Faculty of Arts and Design Education are highly potentials in terms of art skills; a training program in soft skill management is considered as key supporting factors in improving their skills as well as providing practical experiences in art event management.

The training program focuses on the specific set of competencies: 1) Creative economy and tourism competence, regarding concepts of educational tourism events management as essential business development strategy; 2) Entrepreneurial skills, regarding concepts of planning, marketing, organization; 3) Public relation (PR) skills, regarding proper marketing and distribution strategies of products and services to consumers in various segments.

Entrepreneurship is considered the proactive mental attitude one possesses to improve his/her creativity to increase business income. In addition, it is the creative and innovative capability as the basis and resources to achieve success. The aforementioned concepts are crucial as the basis for sparking creative and innovative ideas to nurture the students' entrepreneurial motivation. On the other hand, the empowerment of students as the university's assets and potentials will result in a tangible contribution to the institutional development. Mitchell (2006) argues that empowerment is the internal quality of an individual or organization in adapting oneself with the dynamic environment in its effort of survival and sustainability. The notion of 'empowerment' is embedded within the eight E's, i.e., educate (self-improvement through education), eliminate (problem-solving ability), express (state ideas properly), equip (complement selfweakness), evaluate (evaluation of one's performance), and expect (expectation for a promising future). A sustainable training program is essential in supporting the improvement efforts of students' quality; therefore, every graduate is expected to be competitive in finding jobs or instigating new work opportunities.

Based on the elaborated problem above, this study attempts to conduct an entrepreneurship training program to the students as an extracurricular practical experience regarding art events management by approaches that involve disciplines of management sciences, entrepreneurship, tourism, public relations, and creative arts industry. The training program employed an entrepreneur-based creative economy approach, i.e., the concept of a future economy that relies on human's creativity and competitiveness globally. The students are prepared through a sustainable training and development program; it is viewed as a tangible contribution to the university in actualizing education business-based art events. On that ground, the university requires to optimize all its assets, e.g., infrastructure and human resources to support the implementation of the development program of students' skills and competences in organizing art events.

\section{METHOD}

Training program aims to increase an individual's competencies (Winardi, 2016). Training program on entrepreneurial skills, in particular, intends to provide experience, knowledge, and comprehension to an individual as a means of innovation in one's business; this is particularly related to technical skills, business management skills, and personal entrepreneurial skills (Sugiarto et al., 2015).

The training program implemented 
E3 learning concept related to retailing that aims to enhance students' understanding in following aspects: (1) the market needs; (2) the significance to work in a team to achieve the common goals; (3) the significance of the location of the business; (4) the role of creativity and product and business model innovation; (5) how to manage people; (6) the essence of persistence in achieving the goal; and (7) the proper business practices (Bernardus, 2012). As the program's output, the students were expected to be competent in: 1) analyzing the market's need, 2) organizing the program plan, 3) instigating innovative and creative ideas to adjust with the market trends, 4) managing people and public affairs, and 5) upholding principles of an entrepreneur that is persistent, honest, and responsible.

The training was implemented to students in the Department of Dance Arts Education, Department of Musical Arts Education, and Department of Fine Arts Education in the Faculty of Arts and Design Education in UPI. The students were given practical experiences regarding art events management by approaches that involve disciplines of management sciences, entrepreneurship, tourism, public relations, and creative arts industry. The training program employed an entrepreneurbased creative economy approach, i.e., the concept of a future economy that relies on human's creativity and competitiveness globally. The students were prepared through sustainable training and development program; it is viewed as a tangible contribution to the university in actualizing education business-based art events in accordance with optimization efforts of all its assets to support the implementation of the development program of students' skills.

The training model applied a fourstep model developed by Crone \& Hunter. The model comprised steps i.e.: 1) planning, 2) identification of training program requirements, 3) analysis in the implementation of training program, and 4) evaluation. The model was adopted to adjust to the concept of art events developed by the researcher team.

Based on the model by Crone \& Hunter (Wijaya, 2013), the steps were elaborated as follows: The first step comprised the preparation and arrangement of training program participants. This activity intends to explore the participants' expectations regarding the program's process and output, to nurture intimacy and cooperation between training participants, and to divide training participants into groups and sub-groups.

The second step involved the identification of leaning requirements and analysis of training program objectives. The activities intended to acquire data on the learning requirements from the training participants, the participants' workplace, and/or the training program staff as well as the local community. Moreover, analysis of program objectives was conducted based on the requirements, potentials and possible obstacles discovered throughout the program.

The third step involved the analysis and establishment of the program curriculum by also taking into account the learning outcomes evaluation. The activities focused to analyze and compare between patterns of behavior model the participants displayed throughout the training and the expected participants' behavior after the program.

The fourth step comprised the evaluation of program organization and outcomes. The activity analyzed evaluation strategy on training objectives and processes.

A strategy is a well-designed method implemented to ensure that one can achieve the expected objectives in an accurate manner. In this case, the trainers implemented varied teaching methods and strategies within the program, e.g., demonstration, drill, group project, lecture, question session, and practice. Such innovative methods were expected to contribute significantly to the participants' comprehension of the learning materials. Considering that the learning was intended for adults, therefore, the program implemented problem- 
based participatory learning that as well incorporated the participants' experiences into the learning process.

\section{RESULTS AND DISCUSSION}

Implementation of Edutourism-based Entrepreneurship Training Program

The organization of edutourism management-based entrepreneurship training program is divided into several core materials. The training materials are elaborated in the Table 1.

\section{Entrepreneurial skills}

The incorporation of this topic aims to: 1) develop the participants' business and entrepreneur competencies; 2) train the participants in establishment process of a sustainable business by utilizing existing potentials within the program; and 3) develop the students' ability in creating new job opportunities for themselves and for other people to adjust to the future's career demands.

Developing motivation to be a successful entrepreneur in the art business

The topic discusses tips to be a successful entrepreneur in art business by disseminating best practices materials by the resource person. The participants were introduced examples of successful young entrepreneurs in their respective fields.

\section{Edutourism concepts}

This material discusses the basic concepts of edutourism management that combine visiting activities as well as learning activities for tourists. The basic concept of the edutourism program revolves around the notion of "something to see, something to do, something to buy, and something to learn". Educational Tourism is a program that combines elements of tourism activities with educational content. The educational tourism program aims to provide education and information to tourists about the objects/attractions they visit.

\section{Techniques of art material packaging for tourists}

This material discusses the concept of tourist attractions packaging. Tourist attractions can be interpreted as a tangible or intangible thing that can attract someone to travel to access it. Activities in tourist attractions aim to provide satisfaction to tourists who visit the place. Regarding tourism material packaging, tourist attractions should be able to maintain its sustainability.

\section{Roles of public relations in art events}

This material discusses the importance of public relations as a major part of the marketing aspect. Specifically, this material discusses the relationship of pub-

Table 1. Entrepreneurship training material

\begin{tabular}{ll}
\hline Material & Competence \\
\hline Entrepreneurship & Entrepreneur \\
Developing motivation to be a successful entrepreneur in the art business & Entrepreneur \\
Tips on being a successful entrepreneur in the art business & Entrepreneur \\
Edutourism concepts & Edutourism \\
Edutourism management & Edutourism \\
Edutourism marketing strategy & Edutourism \\
Roles of public relations in art events & Public Relation \\
Management and ethic codes of public relations & Public Relation \\
Public relations and marketing service & Public Relation \\
Concepts of art presentation for education tourism & Tourism art \\
Techniques of art material packaging for tourists & Tourism art \\
Formulating program of art education tourism & Tourism art \\
\hline
\end{tabular}


lic relations with concepts of increasing the public's positive perception of one's business, such as advertising, delivering organizational missions, publications and campaigns in the mass media, as well as promotional skills on various occasions such as seminars or workshops.

\section{Management and ethic codes of public relations}

This material discusses the importance of public relations skills to highlight the organization's positive image in shaping public opinion. In this regard, public relations practitioners must also pay attention to the code of ethics that applies to each place and situation. Public relations activities undertaken by organizations should also prioritize ethics, social responsibility, and sustainability.

\section{Public relations and marketing service}

This material discusses the relationship between public relations and marketing service management. Participants are taught about marketing communication skills in public relations, such as sales promotions. In this activity, a public relations practitioner can provide innovations in organizing sales promotion activities

In addition to sales promotion, a public relations staff must also master publicity skills, manage good relationships, and maintain a positive image of the company in the public eye. This can be done by sponsoring positive activities, engaging in CSR activities, and participating in activities held by the community. Through this material, participants are also taught to maintain a good impression on consumers.

\section{Ways to Build A Mindset of Excellent Management Concepts}

In this material, a mindset involves more advantageous things and prioritizes desires to make a person have a better condition. A positive mindset is required to achieve life success, leading a person to a huge passion. Besides, it will raise preferable behaviors, build strong characteristics and mature personalities to be braver and stronger to face challenges and life problems. A positive mindset comes from a firm reliance and belief of oneself, in which it is able to change one's life to become what s/ he wants to, as well as convincing him/her that $\mathrm{s} /$ he can be better than others. Such concepts of mindset are what people look for and enable them to be more professional.

\section{Art Event Management}

This material explains some examples of how to manage event managementbased arts that have become a trend of today's art events. Event management can be defined as a process of organizing or managing an event professionally, systematically, efficiently, and effectively that the event includes the concepts of planning, implementation, and supervision. Every related party involved in the event management should work hard with the same vision to result in the event that meets the expectation.

\section{Marketing Strategies}

This is an important material for participants to understand (1) Goals and definitions of marketing; (2) How to create an offer that can increase pleasure/perceived value towards the product and service to be sold; (3) How to create an offer that reduce or eliminate unwillingness to buy the product to be sold; (4) How to ease the transaction, so that the buyer will choose your product over others; (5) How to give an interesting and reliable offer.

\section{Arranging the activities of art education tourism program}

The material discusses basic skills in developing an art education tourism program, in which students are given an understanding of how to arrange a quality education tourism program. An example of the best practice in such a program is delivered to them as a reference in developing the program. The instructor directs participants to recall the material that has been explained, and then communicates with and confirms each participant. The 
material is delivered for \pm 3 hours until the participants can make their own study groups.

The evaluation in this art edutourism-based entrepreneur training conducted pre-test and post-test, along with distributing questionnaires. In the evaluation, participants and the authors do an assessment to measure the training effectiveness based on the quality of resource persons, participants, organizing committees, and the whole training implementation. The evaluation instrument comprises several questions that can measure students' absorption ability in scrutinizing the materials, the training and resource persons' quality, and the utilized facilities and infrastructure.

The evaluation result shows that the training process has run effectively following the predetermined plans and goals. The participants feel enthusiastic and can greatly understand and absorb training materials, so that they can apply these directly by following the instruction. Moreover, the final evaluation is carried out to measure the success level of the training process, starting from the planning to the follow-up stages. The whole process of education and training has been wellimplemented. However, the participants find the duration too short, and they need any further activities to practice. The final evaluation done by distributing a questionnaire instrument to participants reveals that $90 \%$ of them have mastered the materials, by which there is a quite significant change before and after the edutourism management-based entrepreneur training. Logic Model

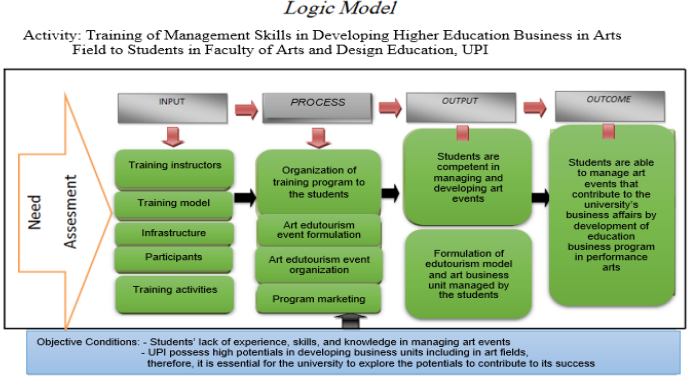

Figure 1. The Stages of Entrepreneur Training Activity

An entrepreneur has some charac- teristics that relate to innovation, proactiveness (able to see market opportunities), and risk-taking, or in other words, an entrepreneur is not afraid of failure in running his/her business (Ranto, 2016).

In a scientific approach, management skills can be approached in three primary competencies. In the first place, a conceptual competence is one's ability to plan a business; secondly, humanity competence refers to a manager's competence in interacting with other people; lastly, technical skill is a provision for managers at lower levels. This skill is more emphasized on the competence to drive facilities or people involved in the activity (Widjaya et al., 2014).

The training program intends to develop students' entrepreneurial skills in managing the art education tourism program. Therefore, the developed materials are divided into three disciplines, i.e., art, tourism, and entrepreneurship. Tourism education, in some developed countries, has been integrated with entrepreneurship education due to the fact that tourism and entrepreneurship education has become an essential aspect for students (Daniel et al., 2017)the number of tourism education courses has grown significantly in the last decades in order to meet the demands of the qualified workforce. Nevertheless, students who enter this sector will need different skills to face the challenges of this highly competitive and demanding industry. In this case, entrepreneurial skills are of paramount importance. The aim of this paper was to understand the perspective of tourism students on the relevance of entrepreneurship education within their courses. This study aims at describing an innovative teaching program called 'Learning to be', focused on fostering entrepreneurial attitudes and skills, through a project based learning methodology inspired in the Design Thinking process (Daniel et al., 2016.

The impact of the training program is based on the initial and final evaluation to find out the effectiveness of the program in growing the spirit of entrepreneurship 
to students at the Faculty of Arts and Design Education, UPI.

The Table 2 shows that the training outcomes arrive at a very good category. The strength analysis in the training is that the students participate in the training attentively by scrutinizing materials, discussing, doing a question-and-answer session, and practicing to make dance costumes and accessories. However, the training program has no sufficient facilities and infrastructure, making it difficult to practice flexibly. In addition, pre-test data show that $63 \%$ of students still lack knowledge and understanding of entrepreneurship. Nevertheless, this percentage continues to increase, in which $77.5 \%$ of students have mastered and understood entrepreneurship, as presented in the post-test data. Of the result, it is expected that entrepreneurial behaviors, i.e., self-confidence, task and outcome-oriented, risk-taking, challenge seeker, leadership, originality, and future-oriented, will be instilled.

Table 2. The Evaluation of Training Outcomes from Test Instrument

\begin{tabular}{|c|c|c|c|c|}
\hline \multirow{2}{*}{$\begin{array}{l}\text { Stu- } \\
\text { dents }\end{array}$} & \multicolumn{2}{|c|}{ Score } & \multirow{2}{*}{ Total } & \multirow{2}{*}{ Average } \\
\hline & Pre-test & Post-test & & \\
\hline 1 & 60 & 85 & 145 & 72.5 \\
\hline 2 & 65 & 75 & 140 & 70 \\
\hline 3 & 45 & 60 & 105 & 52.5 \\
\hline 4 & 65 & 75 & 140 & 70 \\
\hline 5 & 65 & 85 & 150 & 75 \\
\hline 6 & 85 & 90 & 175 & 87.5 \\
\hline 7 & 65 & 90 & 155 & 77.5 \\
\hline 8 & 65 & 70 & 135 & 67.5 \\
\hline 9 & 65 & 75 & 140 & 70 \\
\hline 10 & 35 & 55 & 90 & 45 \\
\hline 11 & 65 & 85 & 150 & 75 \\
\hline 12 & 35 & 65 & 90 & 45 \\
\hline 13 & 45 & 50 & 95 & 47.5 \\
\hline 14 & 70 & 70 & 140 & 70 \\
\hline 15 & 70 & 85 & 155 & 77.5 \\
\hline 16 & 70 & 70 & 140 & 70 \\
\hline 17 & 75 & 90 & 165 & 82.5 \\
\hline 18 & 85 & 90 & 175 & 87.5 \\
\hline
\end{tabular}

\begin{tabular}{ccccc}
19 & 55 & 65 & 120 & 60 \\
20 & 55 & 60 & 115 & 57.5 \\
21 & 70 & 75 & 145 & 72.5 \\
22 & 70 & 90 & 160 & 80 \\
23 & 75 & 80 & 155 & 77.5 \\
24 & 60 & 90 & 150 & 75 \\
25 & 65 & 85 & 150 & 75 \\
26 & 60 & 80 & 140 & 70 \\
27 & 60 & 85 & 145 & 72.5 \\
28 & 65 & 85 & 150 & 75 \\
29 & 60 & 80 & 140 & 70 \\
30 & 60 & 85 & 145 & 72.5 \\
Sum & 1885 & 2325 & 4200 & 2100 \\
Aver- & 63 & 77.5 & 140 & 70 \\
age & & & & \\
\hline
\end{tabular}

The Result of Training and Education Implementation

The success of the training and education implementation is measured by the following components: resource persons, program quality, implementation and service, participant participation. These components in the implementation of management skill training are elaborated below.

\section{Participant Assessment towards Resource Persons}

The Figure 1 provides the detail of participant assessment towards the resource persons.

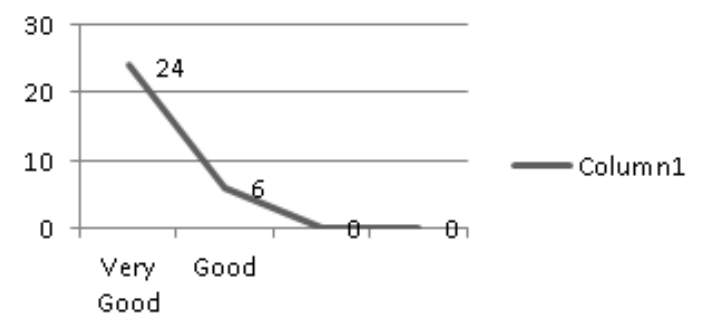

Figure 1. Participant Assessment towards Resource Persons

Based on the Figure 1, 24 participants and six participants state that the resource persons achieve a very good and good category, respectively. Further, all participants are satisfied with the resource persons of the training in making dance costu- 
mes and accessories. They also think about adding other materials to improve their understanding of entrepreneurship and the development of art education tourismbased management given during the training process.

\section{Participant Assessment towards Training Program Quality}

The Figure 2 provides the detail of the quality of management skill training program.

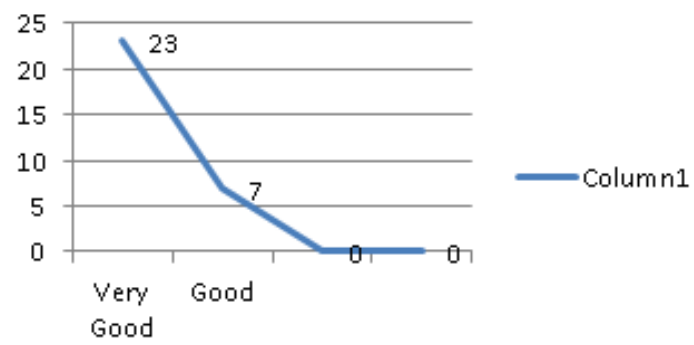

Figure 2. Participants' Satisfaction with the Training Materials

Based on the Figure 2, 23 participants claim that the quality of the training program reaches a very good category, and the other seven participants state that the training has a good quality. The majority of the participants can follow the training materials as in accordance with the goals of the program delivered in the initial activity. However, the participants need a longer time to enhance their mastery.

\section{Participant Assessment towards Training Implementation and Service}

The Figure 3 provides the detail of the implementation and service of management skill training.

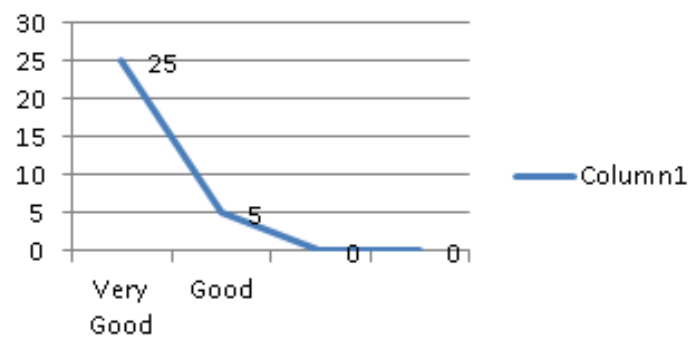

Figure 3. Participant Assessment towards Training Implementation and Service
Based on the above Figure, five participants opine that the quality of the training implementation and service gets a very good category, and the other five participants state that the training has a good implementation and service. Accordingly, most participants give a good assessment towards the implementation and training, although there is one thing that needs to be improved, i.e., a bigger room for participants to join the training more comfortably.

\section{Participant Participation in the Training}

The following Figure provides the detail of student participation in management skill training.

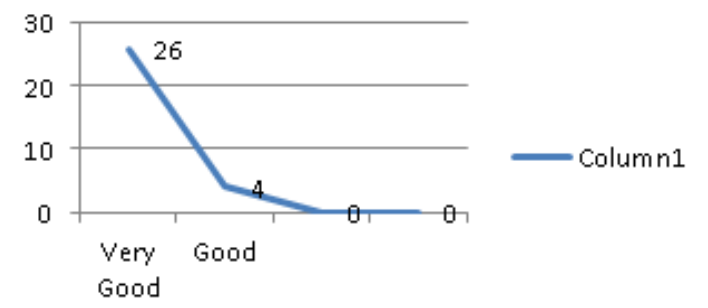

Figure 4. Participant Participation in the Training

The above Figureic presents that 26 and four students reach very good and good participation in the training activities, respectively. Their participation in the art education tourism management-based entrepreneur training mostly arrives at a very good category, in which there is no obstacle faced during the process.

\section{CONCLUSION}

The training is designed to develop students' entrepreneurial skills in managing the art education tourism program. The given materials are more directed to the development of student competences in understanding concepts, theories, and practices of entrepreneurship, education tourism, public relation, and tourism art. Such materials are provided to make students have the competence to manage art education tourism program that will be developed at the Faculty of Arts and De- 
sign Education, UniversitasPendidikan Indonesia.

The two-day training results in a change in students' competencies as shown by the results of the pre- and post-test given before and after the training process. Data processing results also reveal that almost $90 \%$ of the participants experience a change in entrepreneurial behaviors in answering every question during the evaluation stage. Besides, this program gets positive responses from the assessment of participants towards resource persons, resource persons towards participants, and participants towards the implementation with a very good assessment on average.

\section{ACKNOWLEDGMENT}

The authors would like to thank all related parties who have helped the process of conducting the training program at the Faculty of Arts and Design Education, UPI through community service, writing the activity report and this scientific paper to be published in this journal. We also owe a debt of gratitude to the head of Research and Community Service Institute (LPPM) for approving the training proposal and assisting the process of composing the training report for financial support from the university in the 2019 fiscal year.

\section{REFERENCES}

Bernardus, D. (2012). Implementasi Pembelajaran Entrepreneurship Mahasiswa Berbasis The 5E Learning Cycle Model [The 5E Learning Cycle Model-based Student Entrepreneurship Learning Implementation]. Jurnal Entrepreneur Dan Entrepreneurship, 1(1), 11-17.

Daniel, A. D., Costa, R. A., Pita, M., \& Costa, C. (2017). Tourism Education: What about entrepreneurial skills? Journal of Hospitality and Tourism Management, 30(1), 1-8.

Hidayat, N. \& Alhifni, A. (2017). FaktorFaktor yang Mempengaruhi Motivasi Mahasiswa menjadi Entrepre- neur Syariah [Factors Influencing Students to be aSharia Entrepreneur. Jurnal Syarikah, 3(1), 403-418.

Kodrat, D. S., \& Hindarto, P. (2012). Pengaruh Pelatihan Cashflow 101 terhadap Pola Pikir Entrepreneurship Mahasiswa [The Effect of Cashflow 101 Training on Student Entrepreneurial Mindset]. Jurnal Enterpreneur Dan Entrepreneurship, 1(1), 28-33.

Maryanti, S. (2017). Strategi Menumbuhkan Jiwa Enterpreneur Mahasisiwa Di Universitas Lancang Kuning [A Strategy to Grow Students' Spirit of Entrepreneurship at Universitas Lancang Kuning] . Jurnal Pekbis, 9(3), 175-184.

Ndou, V., Mele, G., \& Del-Vecchio, P. (2018). Entrepreneurship Education in Tourism: An Investigation Among European Universities. Journal of Hospitality, Leisure, Sport and Tourism Education, 5(1), 1-11.

Ranto, D. W. P. (2016). Membangun Perilaku Entrepreneur pada Mahasiswa melalui Entrepreneurship Education [Building Students' Entrepreneurial Behaviors through Entrepreneurship Education]. Jbma, 3(1), 79-86.

Sari, T., \& Anita, N. M. (2013). Program Mahasiswa Wirausaha Ni Made Anintia Trisna Sari [Entrepreneurial Student Program Ni Made Anintia Trisna Sari]. Jurnal Pendidikan Ekonomi, 1(1), 64-76.

Stewart, A. M. (2006). Empowering People :Pemberdayaan Sumber Daya Manusia [Empowering People: Human Resources Empowerment]. Yogyakarta: Kanisius.

Sugiarto, J., Wismanto, Y. B., \& Utami, C. T. (2015). Efektivitas Pelatihan Entrepreneurship Skill untuk Meningkatkan Minat menjadi Entrepreneur [The Effectiveness of Entrepreneurial Skills Training to Improve the Interest to be an Entrepreneur]. Prediksi-Kajian Ilmiah Psikologi, 4(1), 51-60.

Widjaya, O. H., Riswanto, \& Suryawan, I. N. (2014). Pengaruh Management 
Skill , Financial Investor dan Human Capital terhadap Women Entrepreneurial Success [The Influence of Management Skill, Financial Investor, and Human Capital on Women Entrepreneurial Success]. Jurnal Bisnis Dan Akuntansi, 16(1), 21-26.

Widyana, I. W., Widyawati, S. R., \& Warmana, G. O. (2018). Pengaruh Pemberian Mata Kuliah Kewirausahaan dan Pelatihan Wirausaha terhadap Minat Wirausaha Ekonomi
Kreatif pada Mahasiswa Unmas Denpasar [The Effect of Entrepreneurship Subject and Training on the Interest in Creative Economy Entrepreneurs of Students at Unmas Denpasar]. Jurnal Bakti Masyarakat Indonesia, 1(1), 171-177.

Winardi, A. (2016). Analisis Penerapan Metode [An Analysis of Method Application]. Kediri: Universitas Nusantara PGRI Kediri. 